\title{
Potential barrier behavior in BiCuVOX materials
}

\section{(Comportamento da barreira de potencial em materiais BiCuVOX)}

\author{
S. M. Gheno, P. I. Paulin F., M.R. Morelli \\ Departamento de Engenharia de Materiais, Universidade Federal de S. Carlos, Rod. Washington Luiz, km 235, \\ C.P. 676, S. Carlos, SP 13565-905 \\ gheno@dema.ufscar.br
}

\begin{abstract}
The BiMeVOX materials appear being high attractive for applications at low temperatures when the ionic conductivity is the determining parameter. The occurrence of many types substitution was confirmed for numerous Me ions, but the greatest interest have been focused on the BiCuVOX materials. The objective of this study was to image the potential barriers in BiCuVOX. The sample was sintered for $4 \mathrm{~h}$ at $750{ }^{\circ} \mathrm{C}$ and the results show that the high density compound can be obtained. Simultaneously, topography and electric force microscopy (EFM) images are viewed side-by-side. EFM experiments were performed and the results show the maps of the electric field distribution on the surface of BiCuVOX. The formation of potential barrier was observed and the width and intensity were measured.
\end{abstract}

Keywords: BiCuVOx, EFM, potential barrier.

\section{Resumo}

Materiais do tipo BiMeVOX são muito atrativos para aplicações em baixas temperaturas quando a condutividade iônica for o parâmetro determinante. A ocorrência de muitos tipos de substituições foi confirmada para numerosos íons Me, dentre os quais, existe um grande interesse no estudo de materiais BiCuVOX. O objetivo deste estudo foi realizar o imageamento das barreiras de potencial em uma amostra de material BiCuVOX. A amostra foi sinterizada 4 h a $750{ }^{\circ} \mathrm{C}$ e apresentou alta densidade. Imagens da superfície topográfica e de microscopia de força elétrica (EFM) foram obtidas simultaneamente em um microscópio de varredura por sonda. Os experimentos EFM mostraram um mapa da distribuição do campo elétrico na superfície do material BiCuVOx. A formação da barreira de potencial foi observada e tanto a largura quanto a altura foram medidas.

Palavras-chave: BiCuVOx, EFM, barreira de potencial.

\section{INTRODUCTION}

The solid electrolytes are materials that block the passage of liquids and gases, but allow the transport of ions through the network when there is a tendency to diffusion. The conductor's oxygen ions are extensively studied and used for a variety of applications, such as oxygen sensors and fuel cells.

Solid electrolytes, also known as fast ionic conductors, are a class of materials with significantly higher low-temperature conductivity than would be expected from a simple statistical assumption regarding the number of vacancies. The measured oxide ion conductivities were indeed quite high, and the transport number near unity [1-3]. Abraham's report spurred a flurry of other papers reporting various partial substitutions of other elements for the $\mathrm{Bi}, \mathrm{V}$, or both metals in the structure, and the resulting modifications to the ionic conductivity [4]. The high oxide ion conductivity reported for the BiMeVOx family is believed to be due to the disorder of the oxygen vacancies that are associated with the vanadium atoms in the perovskitic layer. Mairesse [5] has summarized results for the substitutions of various metal cations onto the vanadium site.

This study was based in ceramic solid electrolytes BiMeVOX (Bi: bismuth, V: vanadium, OX: oxygen and
Me: $\mathrm{Cu}$ ) for conducting oxygen ions, using the method of fusion of oxides as technique of synthesis of the main phase whose compositions are based on the use of $\mathrm{Cu}^{2+}$ metal ions. BiCuVOX has potential applications as a fast ion conducting component in solid oxide fuel cells, oxygen gas sensors and electrochemical pumps for oxygen separation. This material is derived from $\mathrm{Bi}_{4} \mathrm{~V}_{2} \mathrm{O}_{11}$ whereby vanadium is partially substituted by copper. The gamma phase of $\mathrm{Bi}_{4} \mathrm{~V}_{2} \mathrm{O}_{11}$ is the ionic conducting phase. The gamma phase is unstable but can be stabilized by partial substitution with copper or cobalt [6].

\section{MATERIALS AND METHODS}

The materials used as basic reagents in the formulation of $\mathrm{BiCuVOX}$ sample were bismuth oxide $\left(\mathrm{Bi}_{2} \mathrm{O}_{3}\right)$, vanadium oxide $\left(\mathrm{V}_{2} \mathrm{O}_{5}\right)$, copper oxide $\left[\mathrm{Cu}\left(\mathrm{NO}_{3}\right)_{2}\right]$, and titanium oxide $\left(\mathrm{TiO}_{2}\right)$, all from Aldrich.

The powders of crystalline oxides were be prepared with compositions based on the addition of $\mathrm{Cu}^{2+}$ at $\mathrm{BiMeVOX}$ the main stage by fusion of oxides technique. These powders are milled in alcohol medium (balls of zirconia). The samples were compressed in the cylindrical pellets by 
isostatic pressing with a size of approximately $10 \mathrm{~mm}$ in diameter and $3 \mathrm{~mm}$ thick. Before, the sample were submitted to thermal treatment carried out in in air, for appropriated time, temperature and heating rate.

The potential barrier analysis was performed in an atomic force microscope Nanoscope IIIA (Digital Instr.) operating in a electric force microscopy mode (EFM) that was equipped with an extender electronic module (Veeco Instr.). Topographical measurements and electrical data were obtained by the two-pass technique (lift mode). In this configuration, during the first pass, the probe (operating in tapping mode) scans a topographical line. In the second scan, the cantilever is lifted to a predefined distance $(75 \mathrm{~nm})$ in order to minimize the effect of the van der Waals forces, during which it detects variations in the electrical force gradient over the same line and the influence of surface topography is ruled out. A NSC15 tip (MikroMasch) was used in all the experiments. Electrostatic force gradient images were obtained by monitoring the shifts in phase and frequency variations as a function of bias voltages applied
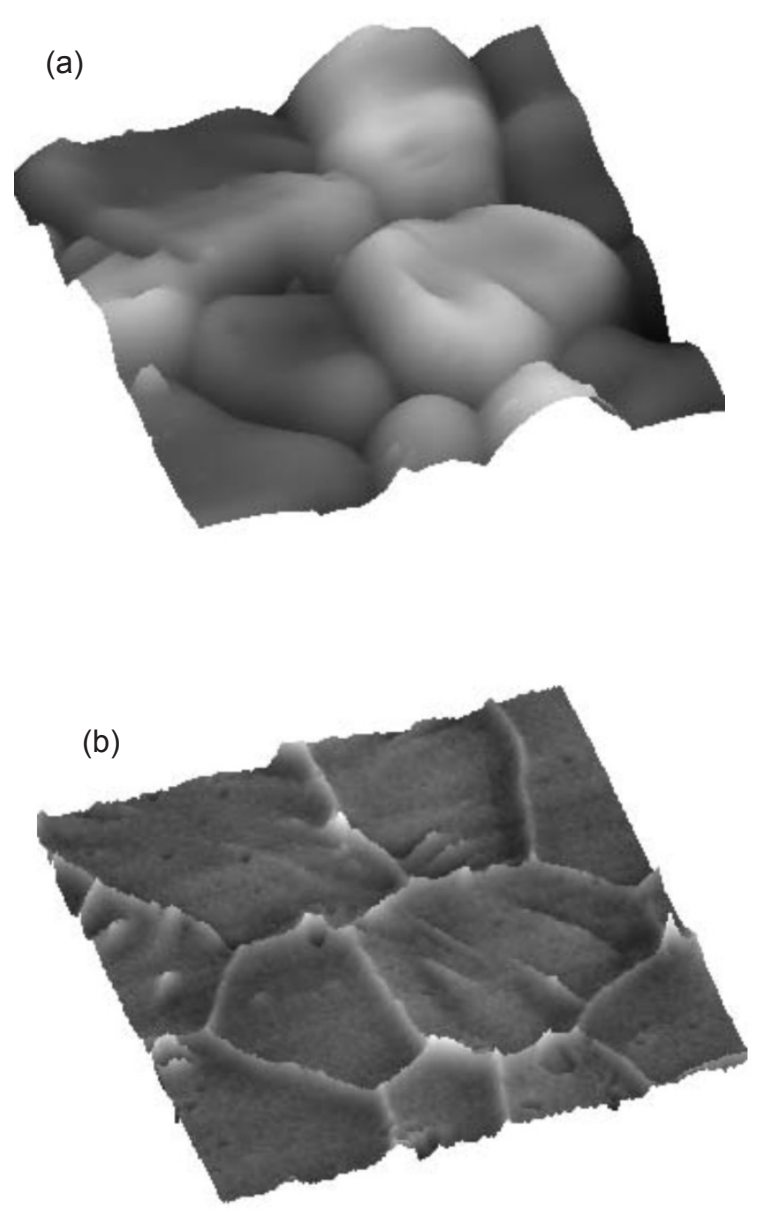

to the cantilever. The initial EFM imaging conditions were: interleave frequency drive, $25 \mathrm{~Hz}$; integral gain, 0.35; proportional gain, 2.5. The images of surface potential and barrier layer were obtained by applying 4,8 and $12 \mathrm{~V}$ in situ to the sample. Imaging was carried out at room temperature.

\section{RESULTS AND DISCUSSION}

The microstructural and electrical properties analysis of BiCuVOX sample was analyzed by scanning probe microscopy (SPM): AFM combined with EFM. The results were analyzed and interpreted using the software DI.

Fig. 1 shows images obtained via AFM/EFM of BiCuVOX when subjected to different voltages. Fig. 1a provides topographic information. The microstructure shows no pores. The grains appear to be homogeneous which indicate that the densification occurred completely.

The EFM results are presented in Fig. 1 (b, c, d, e) with application of external voltage from 4 to $12 \mathrm{~V}$, showing details about the variations in the electric field gradient. The
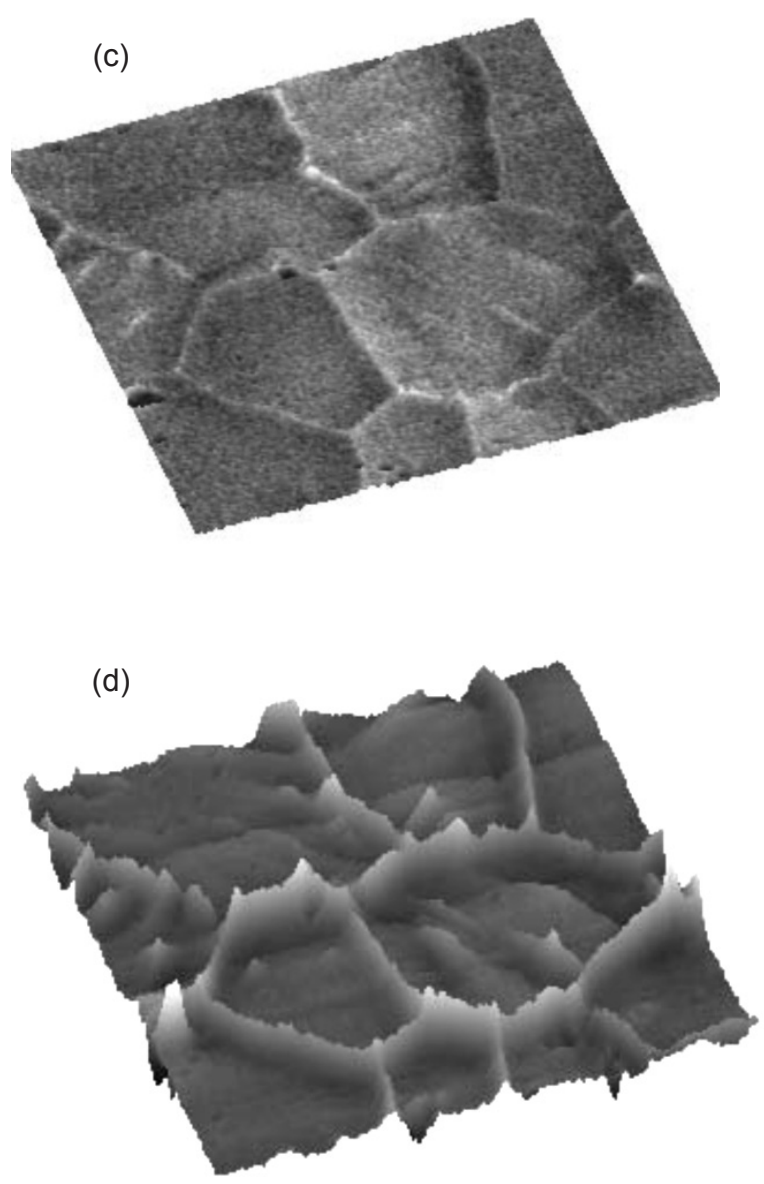

Figure 1: Analysis of BiCuVOX by AFM/EFM: (a) 3D topography image (10 x $10 \times 1.2) \mu \mathrm{m}$; 3D profiles EFM with application of external voltage $(10 \times 10) \mu \mathrm{m}:$ (b) $4 \mathrm{~V}$ (c) $8 \mathrm{~V}$, (d) $12 \mathrm{~V}$.

[Figura 1: Análise de BiCuVOX por AFM/EFM : (a) imagem topográfica $3 D(10 \times 10 \times 1,2) \mu$ m; perfis $3 D$ EFM com aplicação de voltagem externa $(10 \times 10) \mu m:(b) 4 \mathrm{~V}(c) 8 \mathrm{~V}$, (d) $12 \mathrm{~V}$.] 


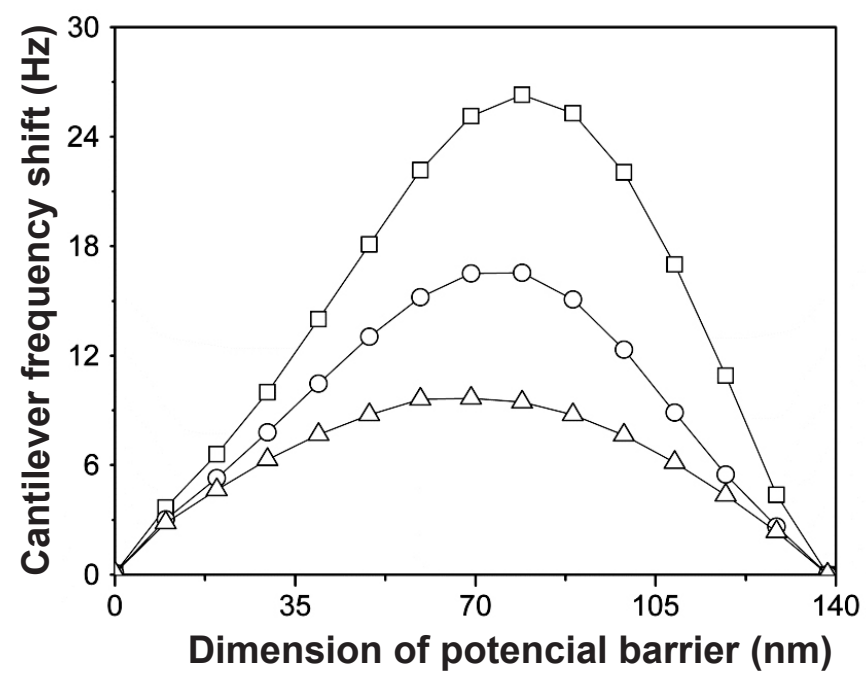

Figure 2: Dimension of potential barrier of $\mathrm{BiCuVOX}$ at 4 $\mathrm{V}(\Delta), 8 \mathrm{~V}(\mathrm{O}), 12 \mathrm{~V}(\square)$.

[Figura 2: Dimensão da barreira de potencial de BiCuVOX em $4 V(\Delta), 8 V(O), 12 V(\square)$.

results presented in EFM images show that the increase of the applied voltage leads to an increase in concentration of negative loads in grain behavior evidencing the presence of effective potential barrier (or attractive).

Potential profiles were extracted from various positions along the grain boundaries of BiCuVOX (Fig. 2). Based on these profiles, the width of the potential barrier in the BiCuVOX sample was $140 \mathrm{~nm}$.

The EFM images show the potential barriers found in the grain contours. The paths of electrical current are those of less resistance, that is, routes with less borders (or larger grains) and those with smaller grain boundary barrier. If the grain size is uniform then more electric current passes through many parallel paths.

The origin of these barriers is interface charge stemming from lattice mismatch, defects and dopants at the grain boundary. The interface charge changes the Fermi level in the vicinity of the grain boundary, with band bending as a result. The electronic charges stored in an interface represent a repulsive potential for the majority carriers - the electrons in the case of an n-doped semiconductor - across the interface.

\section{CONCLUSION}

The use of atomic force microscopy techniques, electric force microscopy, shows a powerful tool in analyzing phenomena associated to grain boundary regions. The potential barriers formed at grain boundaries due segregation of dopants in these regions, as stated in the literature, could be imaged in situ. The potential barriers, due electrical forces developed at interfaces, detected by EFM, are in agreement with theoretical models proposed in the literature.

\section{ACKNOWLEDGEMENTS}

The authors gratefully acknowledge the Brazilian agencies FAPESP and CAPES for their financial support.

\section{REFERENCES}

[1] S. P. Simner, D. Suarez-Sandoval, J. D. Mackenzie, B. Dunn, J. Am. Ceram. Soc. 80, 10 (1997) 2563.

[2] K. R. Kendall, C. Navas, J. K. Thomas, H.-C. Zur Loye, Solid State Ionics 82 (1995) 215.

[3] K. R. Kendall, C. Navas, J. K. Thomas, H.-C. Zur Loye, Chem. Mater. 8 (1996) 642.

[4] F. Abraham, J. C. Boivin, G. Mairesse, G. Nowogrocki, Solid State Ionics 40-41 (1990) 934.

[5] G. Mairesse, in Fast Ion Transport in Solids; B. Scrosati et al, Ed. Kluwer Academic Publ., Netherlands (1993) 271.

[6] M. R. Morelli, S. C. Maestrelli, P. I. Paulin Filho, Condutores ionicos do tipo BIMEVOX obtidos pelo processo de fusão, patente PI 9901973-6 (1999).

(Rec. 27/09/2010, Ac. 22/01/2011) 